\title{
EFFECT OF SOME HONEYBEE PRODUCTS ON CONTROL OF ROOT-KNOT NEMATODE, Meloidogyne javanica ON TOMATO PLANTS \\ Abdel-Aal, A. A. A. ${ }^{1}$ and Neveen M. Galal ${ }^{2}$ \\ 1- Fac. of Agric., Dept. of Eco. Ento.\& Agric. Zoo, Minufiya Univ., Shebin El-Kom, Egypt \\ 2- Nematode Research Dept., Plant Pathology Institute, Agric. Res. Centre, Giza, Egypt
}

\begin{abstract}
This research work was carried out under greenhouse condition to evaluate three different honeybee products i.e. royal jelly, bee venom and propolis at different concentrations to control root-knot nematode, Meloidogyne javanica, on tomato plants. Results of this study revealed that all tested honeybee products at all concentrations significantly reduced all nematode parameters when compared with the treated plants with nematode alone. Applying the royal jelly at the rate of $1 \%$ was the highly effective in reducing all nematode parameters. The highest percentages of reduction in number of galls, egg-masses, developmental stages, females/root system, juveniles in soil, final nematode population (PF) as well as the reproduction factor (RF) were showed with this treatment by $97 ; 99 ; 100 ; 100 ; 92 ; 98$ and $98 \%$, respectively. The treatment of royal jelly at the concentration of $2 \%$ was the second effective one followed by bee venom in the third rank at the concentration of $0.005 \%$. The lowest reduction obtained with the propolis at all tested concentration. Results also showed that all honey bee products at all concentrations enhanced markedly all plant growth parameters i.e. plant height; root length; fresh shoot and root weight. Results revealed that all applied treatments maintained on the cell wall and reduced the membrane permeability compared to plants treated with nematode alone. The lowest percentage membrane permeability (membrane leakage\%) was found with the royal jelly at $1 \%$ as it reached $26 \%$ compared to the treated plants with nematode alone (reached 97\%). The contents of the amino acid proline in plants was also affected with the applied treatments as the highest proline content was obtained with the same treatment of royal jelly at $1 \%$.
\end{abstract}

Keywords: Tomato; Root-knot nematode; Honeybee products; Propolis; Bee venom; Royal jelly.

\section{INTRODUCTION}

Root-knot nematodes, Meloidogyne spp. cause conspicuous root galls and serious reductions in yield of several host plants. They are of major economic significance throughout the tropics and warmer regions of the world. Infected plants suffer from vascular damages which disturb water and mineral uptake (Luc et al., 2005). Although, chemical nematicides hold major effective nematode control (Adegbite and Adesiyan, 2001; Oyedunmade et al., 1992), the high cost, their non-availability at the time of need and the hazards they pose as environmental pollutants, discourage most potential users to search the cheaper and safer alternatives to the chemical nematicides. 
Biological and cultural methods of control the plant pathogens i.e. fungi, bacteria, virus and nematodes were applied. Honeybee products and some of its therapeutic values were mentioned in the Holy Quran. The ancient Egyptians used honey in combination with other herbs and on its own, to treat wounds and diseases of the gut (Zumla and Lulata, 1989). Several authors have reported on the antimicrobial activity of propolis on fungi (Lindenfelser, 1967; Brumfit et al., 1990 and Tosi et al., 1996). Honey bee products i.e. pollen, propolis, bee venom and royal jelly are the promising materials that have antagonistic and medicinal properties against pathogens (Ghanem Nevine, 2011). Several researchers have been reported antimicrobial and antibiotic activities for honey bees and its constituents (Esin Basim et al., 2006). Propolis as a one of honey bee products has a different biological effect such as: antibacterial (Christov et al., 1999; Grange and Darvey, 1990; Menezes et al., 1997); antifungal (Cafarchia et al., 1999; Millertclerc et al., 1987); antiviral (Amoros et al., 1992).

This research work aimed to evaluate the different honeybee products i.e. royal jelly, bee venom and propolis at different concentrations against root-knot nematode, $M$. javanica, on tomato plants.

\section{MATERIALS AND METHODS}

In this research work, three different honeybee products i.e. royal jelly, bee venom and propolis were applied at three different concentrations 1 , 2 and $10 \%(\mathrm{w} / \mathrm{w})$, except bee venom which was used at two different concentrations i.e. 0.005 and $0.0025 \%(\mathrm{v} / \mathrm{w})$. The honeybee products were obtained by collecting from honeybee hives in special apiary at Diarb Negm region, Sharkia governorate. Both royal jelly and propolis were applied by incorporating both of them with the top $10 \mathrm{~cm}$ layer of soil pots at the rate of 1,2 and $10 \%$ of soil weight at transplanting date. The bee venom concentrations were prepared by mixing the bee venom ampoule contents with tap water to prepare the concentrations of 0.005 and $0.0025 \%$.

The experiment was carried out under greenhouse condition at the Experimental farm of Fac. of Agric., Menoufia Univ., Shebin El-Kom, Egypt, in plastic pots $(15 \mathrm{~cm}$ in diam.) filled with sandy-clay soil $(2: 1, \mathrm{v} / \mathrm{v})$. All treatments were applied at the same time of three week-old tomato transplants (Lycopersicon esculentum Mill cv. GS) transplanting into pots (one plant/pot).

Inoculums of root-knot nematode, $M$. javanica was obtained from pure culture of tomato heavily infected roots grown under greenhouse conditions at $25 \pm 2^{\circ} \mathrm{C}$. Eggs of $M$. javanica were extracted from heavily galled roots by using $1.5 \%$ sodium hypochlorite solution $(\mathrm{NaOCl})$ method as described by Hussey and Barker (1973). At the same time of transplanting, two thousand of nematode eggs were inoculated by pipetting into three holes made around the tomato root zone. Each treatment was replicated five times and the non-treated plants were used as control. Plants were arranged in a completely randomized block design in the greenhouse at approximately 
$25 \pm 2^{\circ} \mathrm{C}$. Plants were watered daily and fertilized weekly with a nutrient solution.

After eight weeks of plant inoculation with nematode, plant growth parameters i.e. fresh weights of shoot and root $(\mathrm{g})$, plant height $(\mathrm{cm})$ and root length $(\mathrm{cm})$ as well as membrane integrity (membrane leakage) and the amino acid contents were determined. Nematode parameters i.e. number of galls, number of egg masses/root system, number of eggs/egg-mass, number of females/root system, number of developmental stages/root system, number of juveniles/250 g soil; nematode population and reproduction factor (Goodey, 1957) were also determined. Egg-masses, females and developmental stages were stained prior to counting by dipping the infected roots in $0.015 \%$ phloxine-B solution for 20 minutes as described by Daykin and Hussey (1985).

Membrane Leakage (ML \%) was determined following the method of Leopold et al. (1981). The percentage leakage of solutes was calculated as:

Leakage of substances $(\%)=$ Initial absorbance of bathing medium $\quad \times 100$ Final absorbance at the bathing medium

Final nematode population (PF) was counted according to the equation:

${ }^{*} \mathrm{PF}=$ (No. of egg masses $X$ No. of eggs/egg mass) + No. of females + No. of developmental stages + No. of juveniles in soil pot.

Rate of nematode reproduction (RF) was recorded according to Norton (1978) using the following equation:

${ }^{*} \mathrm{RF}=\mathrm{PF} / \mathrm{Pi} \quad(\mathrm{Pi}=$ initial population $)$

Egg-masses, females and the developmental stages were stained prior to counting by dipping the infected roots in $0.015 \%$ phloxine-B solution for 20 minutes as described by Daykin and Hussey (1985). Females were collected by cutting the root system of each plant in $2 \mathrm{~cm}$ pieces and submerging the roots in a beaker full of tap water for 4 days at room temperature until they became soft. The roots were then washed through 500 and $250 \mu \mathrm{m}$ sieves to separate the females from the root debris (Mahdy, 2002).

Data were statistical analyzed according to standard analysis of variance by a one way ANOVA with the software statgraphics (Statistical Graphics. Crop., Rockville, MD), Variance homogeneity for all treatments was confirmed by the Bartlett test. The comparison between means was carried out by Duncan's Multiple Range Test (Duncan, 1955) as given in the figures.

\section{RESULTS}

Results of this study revealed that all applied honeybee products at all concentrations significantly reduced all nematode parameters i.e. number of galls; egg masses, females/root system, number of juveniles in soil, final nematode population (PF) as well as the reproduction factor (RF) when compared to the plants treated with nematode alone. The reduction 


\section{Abdel-Aal, A. A. A. and Neveen M. Galal}

percentage of nematode parameters ranged between $40-100 \%$. The highest reduction in galls/root system obtained with the application of royal jelly at the concentration of $1 \%$ of soil weight compared to plants treated with nematode alone as shown in Table (1). The percentage of gall reduction was $97 \%$ followed by the royal jelly at $2 \%$ and bee venom at $0.005 \%$ by $87 \%$ for both of them as shown in Table (1). The lowest percentage of reduction was obtained with the application of bee venom at the rate of $0.0025 \%$ as the reduction reached $54 \%$.

Egg masses shown in Table (1) gave the same trend as was found with the number galls as the application of royal jelly at $1 \%$ was the best one. The percentage of reduction in egg masses was recorded $99 \%$ (Table, 1). All the remaining nematode parameters i.e. females; developmental stages; juveniles in soil; nematode final population as well as the reproduction factor (Table, 1) were also significantly reduced with all treatments compared to the treated plants with nematode alone.

Application of royal jelly at $1 \%$ appeared the most effective one in reducing females; developmental stages; juveniles in soil; nematode final population as well as the reproduction factor compared to the others. The percentages of reductions were recorded 100;100; 92; 98 and $98 \%$, respectively as shown in Table (1).

Application the royal jelly at $2 \%$ came in the second rank as the percentage of reduction in females; developmental stages; juveniles in soil; nematode final population and the reproduction factor reached $92 ; 100 ; 88$; 96 and 96 , respectively. The lowest effect recorded with propolis at $2 \%$ as the reduction percentage was $76 ; 40 ; 36 ; 38$ and $38 \%$, respectively.

Results revealed also that all applied honeybee products enhanced markedly all plant growth characters i.e. fresh shoot and root weights, plant and root length (Table, 2), as well as the chemical component of the amino acid proline and at the same time maintained on the root cell wall and reduced its membrane permeability as shown in Table (3), compared to the treated plants with nematode only. Royal jelly product at all used doses showed promise results in this field when compared to the others.

Results confirmed that application royal jelly product at $1 \%$ of soil weight was also the effective one in enhancing all plant growth parameters compared with the others. Proline was also significantly enhanced and the percentage of membrane permeability was reduced with application royal jelly product at $1 \%$ of soil weight compared with the others (Table, 3 ). 
J. Plant Prot. and Path., Mansoura Univ., Vol. 4 (4), April, 2013 
Table (2): Effect of honeybee products on the plant growth characters of infected tomato plants with Meloidogyne javanica.

\begin{tabular}{|c|c|c|c|c|c|c|}
\hline \multirow[b]{2}{*}{ Treatment } & \multirow[b]{2}{*}{$\begin{array}{c}\text { Concentration } \\
(\%)\end{array}$} & \multicolumn{5}{|c|}{ Agronomic characters } \\
\hline & & $\begin{array}{c}\text { Fresh shoot } \\
\text { weight } \\
\text { (g) }\end{array}$ & $\begin{array}{c}\text { Fresh root } \\
\text { weight } \\
\text { (g) }\end{array}$ & $\begin{array}{l}\text { Plant } \\
\text { height } \\
\text { (cm) }\end{array}$ & \multicolumn{2}{|c|}{$\begin{array}{l}\text { Root } \\
\text { length } \\
\text { (cm) }\end{array}$} \\
\hline Royal Jelly & 1 & 23.2 a & $2.80 \quad a$ & $62.0 \quad \mathrm{a}$ & 20.7 & $\mathbf{a}$ \\
\hline Royal Jelly & 2 & $11.7 \mathrm{C}$ & $1.90 \mathrm{ab}$ & 49.3 & 17.0 & $\mathbf{a}$ \\
\hline Royal Jelly & 10 & 15.4 bc & $2.02 a b$ & $61.3 \mathrm{a}$ & 15.7 & $\mathbf{a}$ \\
\hline Bee venom & 0.005 & 15.4 bc & $1.80 \mathrm{ab}$ & $54.3 \mathrm{ab}$ & 16.7 & $\mathbf{a}$ \\
\hline Bee venom & 0.0025 & 14.2 bc & $1.90 \mathrm{ab}$ & $58.7 \quad a b$ & 17.7 & $\mathbf{a}$ \\
\hline Propolis & 1 & 17.9 abc & $2.30 \mathrm{ab}$ & $45.7 \quad a b$ & 21.0 & $\mathbf{a}$ \\
\hline Propolis & 2 & 16.2 bc & $1.40 \quad b$ & $61.0 \quad a$ & 20.3 & $\mathbf{a}$ \\
\hline Propolis & 10 & $11.9 \mathrm{C}$ & $1.70 \quad b$ & $60.0 \quad a$ & 19.7 & $\mathbf{a}$ \\
\hline \multicolumn{2}{|c|}{ Nematode alone ( Control +) } & 16.7 bc & $1.60 \mathrm{~b}$ & 53.0 & 13.0 & $\mathbf{a}$ \\
\hline \multicolumn{2}{|l|}{ Control (-) } & $18.5 \mathrm{ab}$ & $2.30 \mathrm{ab}$ & $40.3 \quad b$ & 18.7 & $\mathbf{a}$ \\
\hline
\end{tabular}

* Means followed by the same letters within a column are not significantly different by $(P=0.05)$ according to Duncan's multiple range test.

Table (3): Effect of honeybee products on the amino acid proline content and the membrane leakage \% of infected tomato plants with Meloidogyne javanica.

\begin{tabular}{|l|c|c|c|}
\hline Treatment & $\begin{array}{c}\text { Concentration } \\
(\%)\end{array}$ & $\begin{array}{c}\text { Proline content } \\
(\mu \mathrm{g} / \mathrm{g} \mathrm{dw})\end{array}$ & $\begin{array}{c}\text { Membrane } \text { leakage }^{\star *} \\
(\%)\end{array}$ \\
\hline Royal Jelly & 1 & $3.3 \mathrm{a}$ & 0.26 \\
\hline Royal Jelly & 2 & $2.0 \mathrm{~b}$ & 0.65 \\
\hline Royal Jelly & 10 & $1.1 \mathrm{~d}$ & 0.77 \\
\hline Bee venom & 0.005 & $0.2 \mathrm{j}$ & 0.91 \\
\hline Bee venom & 0.0025 & $0.3 \mathrm{i}$ & 0.63 \\
\hline Propolis & 1 & $0.6 \mathrm{~g}$ & 0.96 \\
\hline Propolis & 2 & $0.9 \mathrm{e}$ & 0.95 \\
\hline Propolis & 10 & $1.6 \mathrm{c}$ & 0.92 \\
\hline Nematode alone (Control +$)$ & $0.7 \mathrm{f}$ & 0.97 \\
\hline Control (treatment free) & $0.5 \mathrm{~h}$ & 0.75 \\
\hline
\end{tabular}

Means followed by the same letters within a column are not significantly different by $(P=0.05)$ according to Duncan's multiple range test.

${ }^{* *}$ Membrane leakage $(\%)=$ Initial absorbance of bathing medium $\quad \times 100$ (Leopold et al., 1981). Final absorbance at the bathing medium

\section{DISCUSSION}

Results of this study revealed that all tested honeybee products at all tested concentrations significantly reduced all related nematode parameters i.e. number of galls, number of egg-masses, number of developmental stages, number of females/root system, number of juveniles in soil, final nematode population (PF) as well as the reproduction factor (RF) when compared to the treated plants with nematode alone. Results confirmed that applying the royal jelly at the rate of $1 \%$ was the highly effective treatment in reducing all nematode parameters.

Honeybee products have been found to contain significant antioxidant compounds, but in lower concentration: glucose oxidase, 
catalase, ascorbic acid, flavonoids, phenolic acids, carotenoid derivatives, organic acids, amino acids and proteins (Bogdanov, 2011). He found that also royal jelly have antibacterial, antifungal and antiviral antioxidative.

Fujiwara et al., (1990) revealed that the peptide royalisin isolated from royal jelly have antibacterial activity against some gram positive bacteria. A special group of protective substances in the developing organism of honeybee is represented by proteins and peptides and by molecular weight compounds present in royal jelly. The antibacterial activity of 10-hydroxytrans-2-decenoic acid, the natural component of royal jelly was described (Bonvehl and Jorda, 1991).

Ali and Abd El-Ghafar (2002) evaluated three concentrations 1, 5 and $10 \%$ from each of royal jelly and propolis as well as sterilized and nonsterilized bee honey for controlling Ascospherea apis and Aspergillus flavus fungi that cause chalk and stone brood in honeybee colonies. They found that royal jelly and propolis at $10 \%$ significantly inhibited the fungi growth area when compared with untreated check. Bamford (1987) stated that royal jelly exhibited a severe inhibition effect on all germination stages of the fungus Ascospherea apis.

According to Chu et al., (1992) the presence of 10-hydroxy-2decanoic acid (10-HAD) in royal jelly plays an important role in inhibiting growth or promoting sporulation of Ascospherea apis.

The proteins secreted by honeybees into royal jelly and other hive products have different roles in the functioning of a honeybee colony as a superorganism. The low-molecular weight proteins and peptides of royal jelly might play a host-defense role against pathogens as reported by Bilikova et al., (2001).

The spectrum of biological activity of royalisin was broadened by discovering its antifungal activity against Botrytis cinerea. It is possible to suggest that royalisin exhibits both antibacterial and antifungal properties. This finding corresponds with the data on defense of insects against pathogens that were essentially based on synthesis of cationic peptides/polypeptides exhibiting a broad spectrum of antimicrobial and antifungal activity (Bulet et al., 1999; Otves, 2000).

Royal jelly have antioxidant properties including scavenging activity of 1,1-diphenyl-2-picrylhydrazyl (DPPH) radicals, inhibition of linoleic acid peroxidation. Royal jelly in addition has higher contents of proteins and polyphenolic compounds, which may be the major component for giving the antioxidant activities in royal jelly http://www.indiamart.com/akashinternational-mumbai/other-products.html.

Noweer and Dawood (2009) found that soil drench with some honeybee product extracts (propolis) increased protein content. The data revealed that the propolis extract as soil drench reduced the juvenileMeloidogyne sp. population density/one kg soil and number of root-galls/one gm roots

Noweer and Dawood (2009) found that the qualitative of some honeybee product extracts (propolis) proved that these extracts contain sterols, flavonoids and phenolic compounds as well as a few numbers of 


\section{Abdel-Aal, A. A. A. and Neveen M. Galal}

phenolic acids i.e. coumaric, ferulic, salicylic and benzoic acid. They found that also, all treatments of propolis extract either as foliar or soil drench application increased total chlorophyll, carotenoid and protein contents of faba bean plants. All propolis extracts enhanced plant growth characters i.e. shoot height; root dry weight; number of branches and pods/plant; number of seeds/pod as well as seed index.

\section{REFERENCES}

Adegbite, A. A. and Adesiyan, S. O. (2001). Efficacy of carbofuran on the performance of four nematode susceptible varieties of soybean (Glycin max (L.) Merrill). Tropical Oil Seeds J., 6: 11-23.

Ali, M. A. and Abd El-Ghafar, N. Y. (2002). Laboratory evaluation of some honey bee products against Ascospherea apis and Aspergillus flavus. Research: 118-125.

Amoros, M.; Sauvager, F.; Gire, L. and Cormier, M. (1992). In vitro antiviral activity of propolis. Apidologie, 23: 231-240.

Bamford, S. (1987). Studies on the infection of honey bee larvae with Ascospherea apis. Bibliographic Citation: 200pp.

Bilikova, K.; Wu, G. and Simuth, J. (2001). Isolation of a peptide fraction from honeybee royal jelly as a potential antifoulbrood factor. Apidologie 32: 275-283.

Bogdanov, S. (2011). Functional and Biological Properties of the Bee Products: a Review. Bee Product Science: 1-12.

Bonvehí, J. S. and Jordá, R. E. (1991) Studie über die mikro-biologische Qualität und bacteriostatische Aktivität des Weiselfuttersaftes (Gelée Royale): Beein-flussung durch organische Säuren. Deutsche Lebensmittel-Rundschau 87: 256-259.

Bulet, P.; Hetru, C.; Dimarcq, J. and Hoffmann, D. (1999). Antimicrobial peptides in insects; structure and function, Dev. Comp. Imunol. 23: 329-344.

Cafarchia, C.; de Laurentis, N.; Milillo, M. A.; Losacco, V. and Puccini, V. (1999). Antifungal activity of Apulia region propolis. Parasitologia, 41: 587-590.

Christov, R.; Bankova, V.; Tsvetkova, I.; Kujumgiev, A. and Tejera, A. D. (1999). Antibacterial furofuran lignans from Canary Islands propolis. Fitoterapia, 70, 89-92.

Chu, L. K.; Liu, T. M. and Ho, K. K. (1992). Growth inhibition of Ascospherea apis by royal jelly and 10-hydroxy-2-decanoic acid. Bull. Instit. Zool., Acad. Sinica, 31 (2): 73-79.

Daykin, M. E. and Hussey, R. S. (1985). Staining and histopathological techniques in nematology. Pp. 39-48 in Barker, K. R.; Carter, C. C. and Sasser, J. N., Eds. An advanced treatise in Meloidogyne, Vol. II Methodology, Raleigh: North Carolina State University Graphics.

Duncan, B. (1955). Multiple ranges and multiple F. test. Biometriex, 11: 1-42. 
Esin Basim; Hueseyin Basim and Musa Oezcan (2006). Antibacterial activities of Turkish pollen and propolis extracts against plant bacterial pathogens. Journal of Food Engineering 77: 992-996.

Fujiwara, S.; Imai, J.; Fujiwara, M.; Yaeshima, T.; Kawashima, T. and Kobayashi, K. (1990). A potent antibacterial protein in royal jelly. J. Biol. Chem. 265: 11333 - 11337.

Ghanem Nevine, B. (2011). Study on the antimicrobial activity of honey products and some Saudi Folkloric substance. Research Journal of Biotechnology Vol. 6 (4): 38-43.

Goodey, J. B. (1957). Laboratory methods for work with plant and soil nematodes. Tech. Bull. No.2, Min. Agric. Fish, Ed. London pp 47.

Grange, J. M. and Darvey, R. W. (1990). Antibacterial properties of propolis (bee glue). Journal of the Royal Society of Medicine, 83: 159-160.

Hussey, R. S. and Barker, K. R. (1973). A comparison of methods collecting inocula of Meloidogyne spp. including a new technique. Plant Disease Reporter 57: 1025-1028.

Leopold, A. C.; Musgrave, M. E. and Williams, K. M. (1981). Solute leakage resulting from leaf desiccation. Plant Physiol., 68: 1222-1225.

Luc, M.; Sikora, R. A. and Bridge, J. (2005). Plant parasitic nematodes in tropical and subtropical agriculture. Pp. 675, $2^{\text {nd }}$ Edition, $C A B$ International, Wallingford, Oxon, UK.

Mahdy, M. E. (2002). Biological control of plant parasitic nematodes with antagonistic bacteria on different host plants. Ph.D Thesis, Bonn University, Germany, pp.171.

Marcucci, M. C. (1995). Propolis: chemical composition, biological properties and therapeutic activity. Apidologie, 26, 83-89.

Menezes, H.; Bacci, M. Jr.; Oliveria, S. D. and Pagnocca, F. C. (1997). Antibacterial properties of propolis and products containing propolis from Brazil. Apidologie, 28, 71-76.

Millert-Clerc, J.; Michael, D.; Simeray, J. and Chaumont, J. P. (1987). Etude preliminaire des proprietes fongistatiques de la propolis com-parees a celles de quelques produits commerciaux. Plantes Me dicinales et Phytotherapie, 21: 3-7.

Norton, D. C. (1978). Ecology of Plant Parasitic Nematode. John Willey and Sons, New York, p. 238.

Noweer, E. M. and Dawood, M. G. (2009). Efficiency of propolis extract on faba bean plants and its role against nematode infection. Commun Agric Appl Biol Sci. 74(2): 593-603

Otvos, L. J. R. (2000). Antibacterial peptides isolated from insects. J. Peptide Sci. 6:4

Oyedunmade, E. A.; Adesiyan, S. O. and Aduloju, M. (1992). Efficacy of phorate application in the control of root-knot nematodes on two soybean varities. Nig. J. Plant Prot., 14: 82-87.

http://www.indiamart.com/akash-international-mumbai/other-products.html. 
تأثير بعض منتجات نحل العسل على مكافحة نيمـاتودا تعقد الجذور المتواجدة علمات

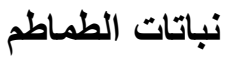

أحمد عبد القوى عبداتلعال 1 و نيفين مجدي جلال 2

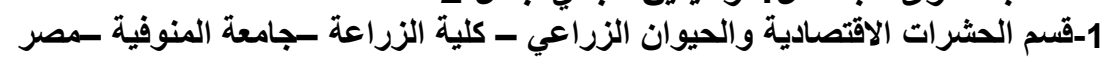

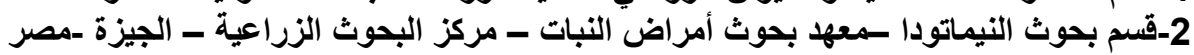

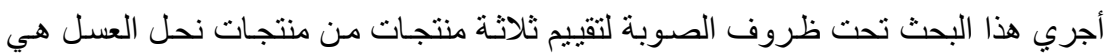

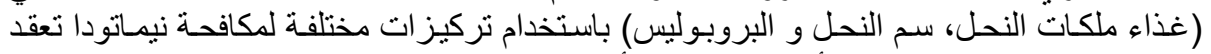

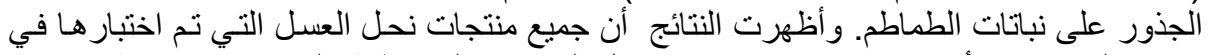

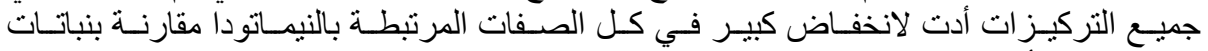

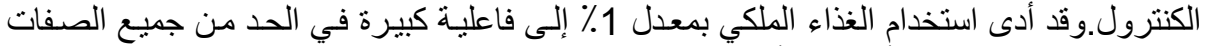

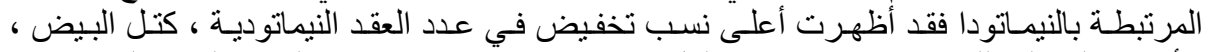

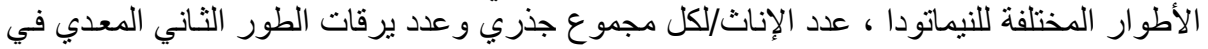

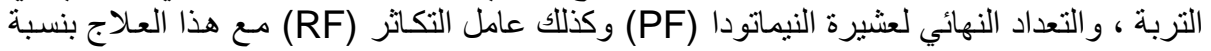

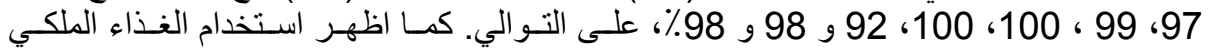

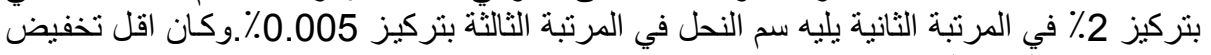
عند استخدام البروبوليس بجميع تركيز اته.

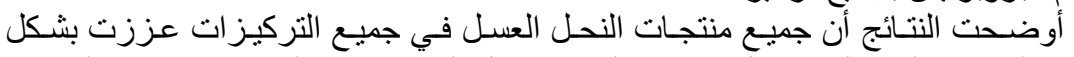

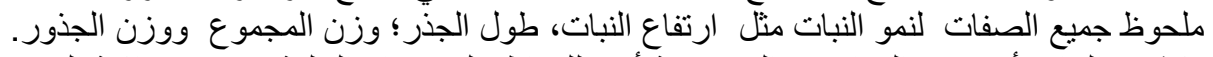

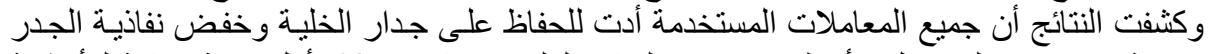

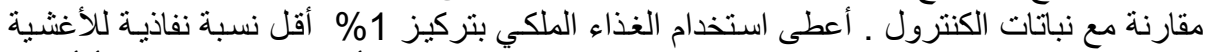

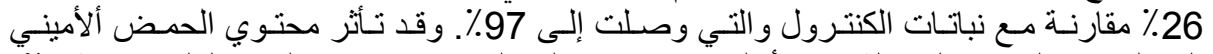

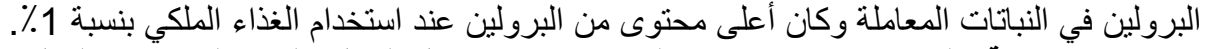
الكلمات المفتاحية: الطماطم ، نيماتودا تعقد الجذور ، منتجات نحل العبل العل، البروبوليس ، سم النحل ،

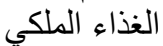

كلية الزراعة - جامعة المنصورة قام بتحكيم البحث كلية الزراعة - جامعة المنوفيه

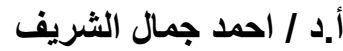
أ. أد / محمد نظيم سيد احمد الثريف 
J. Plant Prot. and Path., Mansoura Univ., Vol. 4 (4), April, 2013 
Table (1): Effect of honeybee products on the nematode parameters of tomato plants infected with Meloidogyne javanica.

\begin{tabular}{|c|c|c|c|c|c|c|c|c|c|c|c|c|c|c|c|}
\hline \multicolumn{16}{|c|}{ Javanica. } \\
\hline \multirow[b]{2}{*}{ 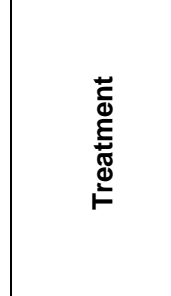 } & \multirow{2}{*}{ 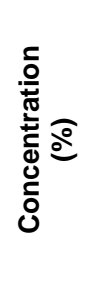 } & \multirow[b]{2}{*}{ 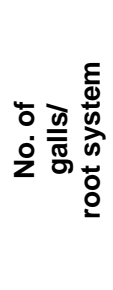 } & \multirow[b]{2}{*}{ 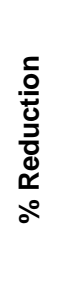 } & \multicolumn{8}{|c|}{ Nematode Parameters / Population } & \multirow{2}{*}{ 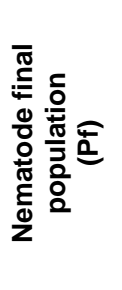 } & \multirow[b]{2}{*}{ 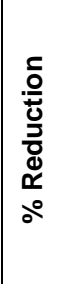 } & \multirow{2}{*}{ 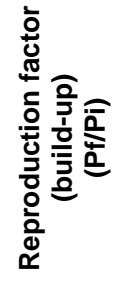 } & \multirow[b]{2}{*}{ 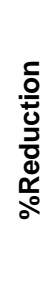 } \\
\hline & & & & 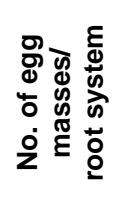 & 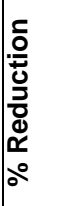 & 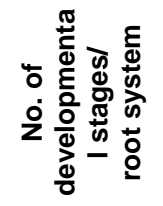 & 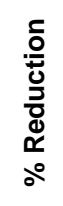 & 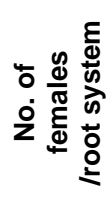 & 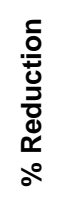 & 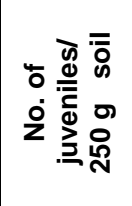 & 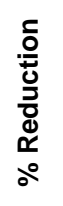 & & & & \\
\hline Royal Jelly & 1 & $2.30 \mathrm{f}$ & 97 & $0.30 \mathrm{~d}$ & 99 & $0.00 \mathrm{c}$ & 100 & $0.00 \mathrm{~b}$ & 100 & $333.30 \mathrm{c}$ & 92 & 342.300 & 98 & 0.17 & 98 \\
\hline Royal Jelly & 2 & 9.00 ef & 87 & $1.00 \mathrm{~cd}$ & 96 & $0.00 \mathrm{c}$ & 100 & $6.70 \mathrm{~b}$ & 92 & \begin{tabular}{|l|}
$500.00 \mathrm{c}$ \\
\end{tabular} & 88 & 566.700 & 96 & 0.28 & 96 \\
\hline Royal Jelly & 10 & $15.0 \mathrm{de}$ & 79 & $5.00 \mathrm{bc}$ & 81 & $50.0 \mathrm{ab}$ & 40 & $16.7 \mathrm{~b}$ & 80 & \begin{tabular}{|l|}
$733.30 \mathrm{c}$ \\
\end{tabular} & 82 & 1200.00 & 92 & 0.60 & 92 \\
\hline Bee venom & 0.005 & 9.30ef & 87 & $2.30 \mathrm{~cd}$ & \begin{tabular}{|l|}
91 \\
\end{tabular} & $16.7 \mathrm{bc}$ & 80 & $6.70 \mathrm{~b}$ & 92 & $333.30 \mathrm{c}$ & 92 & 540.700 & 96 & 0.27 & 96 \\
\hline Bee venom & 0.0025 & $32.7 \mathrm{~b}$ & 54 & $7.00 \mathrm{~cd}$ & 74 & $16.7 \mathrm{bc}$ & 80 & $10.0 \mathrm{~b}$ & 88 & $616.70 \mathrm{c}$ & 85 & 1413.40 & 91 & 0.71 & 91 \\
\hline Propolis & 1 & $30.3 \mathrm{bc}$ & 57 & $8.30 \mathrm{~b}$ & \begin{tabular}{|l|}
69 \\
\end{tabular} & 33.3bc & 60 & $16.7 \mathrm{~b}$ & 80 & $800.00 \mathrm{c}$ & 80 & 2344.00 & 83 & 1.17 & 85 \\
\hline Propolis & 2 & $20.7 \mathrm{~cd}$ & 71 & $8.60 \mathrm{~b}$ & 68 & $50.0 \mathrm{ab}$ & 40 & $20.0 \mathrm{~b}$ & 76 & $2566.7 \mathrm{~b}$ & 36 & 9356.70 & 38 & 4.68 & 38 \\
\hline Propolis & 10 & 17.3de & 76 & $4.30 \mathrm{bcd}$ & 84 & $16.7 \mathrm{bc}$ & 80 & $20.0 \mathrm{~b}$ & 76 & $666.70 \mathrm{c}$ & 83 & 1090.40 & 93 & 0.54 & 93 \\
\hline \multicolumn{2}{|c|}{$\begin{array}{l}\text { Nematode alone } \\
\text { (control }+ \text { ) }\end{array}$} & $71.0 \mathrm{a}$ & & $26.7 \mathrm{a}$ & & $83.3 a$ & & $83.3 \mathrm{a}$ & & $4000.0 \mathrm{a}$ & & 15113.6 & & 7.56 & \\
\hline
\end{tabular}

